\title{
ON THE NATURE OF CORPORATIONS
}

\section{LYNN A Stout*}

[Legal experts traditionally distinguish corporations from unincorporated business forms by focusing on such corporate characteristics as limited shareholder liability, centralised management, perpetual life, and freely transferred shares. While this approach has value, this essay argues that the nature of the corporation can be better understood by focusing on a fifth, often-overlooked, characteristic of corporations: their capacity to "lock in" equity investors' initial capital contributions by making it far more difficult for those investors to subsequently withdraw assets from the firm. Like a tar pit, a corporation is much easier for equity investors to get into, than to get out of.

An emerging school of theorists has begun to explore the implications of this idea for corporate law and practice. The idea is still novel enough to lack a uniformlyaccepted label -in addition to the phrase "capital lock-in," scholars have described this aspect of incorporation as "affirmative asset partitioning," "the absence of a repurchase condition," and "asset separation from shareholders." Whatever label one chooses, the idea shows great promise for illuminating a variety of thorny problems that have long troubled corporate scholars and practitioners.

In illustration, this essay considers how the idea of capital lock-in sheds light on three corporate mysteries in the United States: the sui generis nature of corporate directors' fiduciary duties; the rise of the large modern service partnership; and lawmakers' enthusiasm for meddling with corporate governance rules.]

\footnotetext{
" Professor of Law, University of California at Los Angeles School of Law; Principal Investigator, UCLA-Sloan Research Program on Business Organizations. This Essay is based on remarks prepared for the University of Illinois College of Law Conference on Uncorporation: A New Age, held on April 23, 2004, in Chicago, Illinois. I would like to thank the participants at that conference for their many helpful questions and remarks. I am also indebted to Iman Anabtawi, Stephen Bainbridge, Steven Bank, Margaret Blair, Harold Demsetz, Victor Fleischer, Bob Hillman, Bill Klein, Lynn LoPucki, and Larry Ribstein for helpful comments on earlier drafts. A slightly modified version of this article will be published in a forthcoming edition of the University of Illinois Law Review.
} 


\section{INTRODUCTION}

Whenever lawyers discuss the differences between corporations and unincorporated business forms, one is inevitably reminded of the parable of the four blind men and the elephant. Four blind men were invited to touch an elephant in order to learn more about its nature. Approaching the elephant, the first blind man took hold of its trunk. "Aha!" he cried. "The elephant is like a snake." The second blind man grabbed the pachyderm's tail. "No," he said, "the elephant is like a rope." The third blind man grasped a leg and announced, "I disagree. The elephant is like a tree." The fourth blind man placed his palms against the animal's side. "You are each mistaken," he observed. "The elephant is like a wall."

Something similar happens whenever legal experts gather together to debate the essential difference between corporations and unincorporated business forms such as partnerships or proprietorships. Some say limited liability is the key, and that what makes a corporation a corporation is the fact that equity investors are not personally liable for the entity's debts. Others argue that the hallmark of a corporation is the centralisation of control in the hands of a small group of individuals. Still others focus on the corporate characteristic of perpetual life, or the opportunity public corporations offer equity investors to freely transfer their shares in a liquid secondary market. ${ }^{1}$

Each view is correct in its fashion. Yet my sympathies lie with the arguments of an alternative, emerging school of corporate theorists. These theorists might be likened to the fourth blind man who thought the elephant was like a wall. They argue that the corporation also is like a wall-or, as some of the new school have put it, like a partition.

\footnotetext{
1 Any student of corporate law is likely to recognise this list of characteristics as the four factors often cited as the essential and distinguishing marks of the corporate form. See, for example, Robert C Clark, Corporate Law (1986) 2 (citing these four factors); Steven A Bank, 'Federalizing the Tax-Free Merger: Toward An End to the Anachronistic Reliance on State Corporation Laws' (1999) 77 North Carolina Law Review 1307, 1364-65 (describing how tax law traditionally used these four factors to distinguish corporations from other business forms).
} 


\section{II “CAPITAL LOCK-IN” AND SPECIFIC INVESTMENT}

I am referring here to an idea that has been percolating through corporate scholarship only for the past decade or so. As a result it is still new enough to lack a universally-accepted label. Henry Hansmaan and Reinier Kraakman have coined the phrase 'affirmative asset partitioning' to describe this important and increasingly talked-about characteristic of incorporated business. ${ }^{2}$ Economist Harold Demsetz has described it as 'the absence of a repurchase condition,' ${ }^{3}$ while Bill Klein and Jack Coffee use the phrase 'asset separation from shareholders. ${ }^{4}$ In a recent article exploring the idea in depth, Margaret Blair has employed the pithy term "capital lock-in' to capture this essential characteristic of the corporation form. ${ }^{5}$

Whatever label one chooses--I adopt 'capital lock-in' below, on grounds of brevity and concreteness--the underlying idea is straightforward. In brief, an essential if often-overlooked difference between unincorporated and incorporated business forms lies in the latter's capacity to make it easier for equity investors to commit their financial contributions irretrievably to the firm. A corporation's assets belong to the corporation, and not to its equity investors. As a result, those assets cannot be unilaterally withdrawn from the firm by either its shareholders, or by the creditors of its shareholders.

To see how corporations differ from partnerships in this regard, consider the case of Adam, Betty, and Charlie, who each want to construct a widget factory. No single one of them has enough financial capital to undertake the project. Adam, Betty, and Charlie consequently decide to pool their resources, each contributing a third of the money needed. If they do this under the default rules of partnership law, any one of the three investors can unilaterally demand the partnership be dissolved and the value of its assets distributed back to the partners-even if this requires the widget

\footnotetext{
${ }^{2}$ See Henry Hansmann and Reinier Kraakman, 'The Essential Role of Organizational Law' (2000) 110 Yale Law Journal 387.

${ }^{3}$ See Harold Demsetz, The Economics of the Business Firm: Seven Critical Commentaries (1995) 50-1.

${ }^{4}$ See William A Klein and John C Coffee, Business Organization and Finance: Legal and Economic Principles $\left(9^{\text {th }}\right.$ ed, 2004) 108.

${ }^{5}$ See Margaret M Blair, 'Locking In Capital: What Corporate Law Achieved for Business Organizers in the Nineteenth Century' (2003) 51 UCLA Law Review 387. The idea of capital lock-in both supports and is supported by other recent developments in corporate theory. For example, in a series of articles written both alone and together, Margaret Blair and I have catalogued the many ways in which the law and practice of director governance in modern public corporations limits the ability of shareholders and other groups to withdraw assets from the firm without director approval, thus protecting and encouraging firm-specific investment. See Margaret M Blair and Lynn A Stout, 'A Team Production Theory of Corporate Law' (1999) 85 Virginia Law Review 247, 275, 278; see also Margaret M Blair and Lynn A Stout, 'Director Accountability and the Mediating Role of the Corporate Board' (2001) 79 Washington University Law Quarterly 403; Lynn A Stout, 'Bad and Not-So-Bad Arguments for Shareholder Primacy' (2002) 75 Southern California Law Review 1189; Lynn A Stout, 'The Shareholder As Ulysses' (2003) 152 University of Pennsylvania Law Review 667. Stephen Bainbridge has also emphasised the importance of director governance for different reasons. See Stephen M Bainbridge, 'Director Primacy: The Means and Ends of Corporate Governance' (2003) 97 Northwestern University Law Review 547.
} 
factory to be dismantled or sold off. ${ }^{6}$ In essence, each partner retains the right to demand the return of the value of his or her interest in the partnership.

In contrast, if Adam, Betty and Charlie form a corporation and each contributes money in return for one-third of its shares, it now becomes far more difficult for any one of the three to unilaterally withdraw the value of his or her share. Under the default rules of corporate law, a shareholder who wants his or her money back must either (1) find a buyer willing to pay full price for his or her shares; (2) convince the corporation's board of directors to repurchase them; or (3) petition a court for redress (an unlikely scenario). Like a tar pit, a corporation is much easier for an equity investor to get into, than to get out of.

This quality of corporate entities-whether called affirmative asset partitioning, capital lock-in, or the absence of a repurchase condition-may come closer than any other to capturing the essential difference between incorporated and unincorporated business forms. It may also go a long way towards explaining why the corporation has evolved into the dominant business form for pursuing certain kinds of large, long-term economic projects.

To understand why, it is essential to recognise that while capital lock-in on first inspection seems to disadvantage equity investors, it offers important benefits for certain kinds of production. In particular, a capacity to lock in investment capital may be essential for projects that require large amounts of firm-specific assets, meaning assets that cannot be withdrawn from the firm without destroying much of their value. Specific assets can take a variety of forms. They include, for example, sunk-cost investments-past expenditures of time or money made in the hope of future rewards. Highly specialised equipment that cannot be easily converted for other uses also is firm-specific. (The left rail of a railroad track is useless without the right rail). A third example is firm-specific human capital-managers' and employees' investment in knowledge, skills, and contacts that are uniquely useful to their present firm, and of little value to other potential employers. ${ }^{7}$

The problem posed by firm-specific investment, and the way incorporation helps to solve it, can be illuminated by considering again the case of Adam, Betty, and Charlie. Suppose each contributes a third of the money needed to construct a customised widget manufacturing facility. Once the money is spent and the factory

\footnotetext{
${ }^{6}$ See R. U. P. A $\$ \S 801-807$ (describing rules for dissolving and winding up partnerships after disassociation of partner); see also R. U. L. P. A $\S \S 801-812$ (describing rules for dissolving and winding up limited partnerships after disassociation of general partner). Similar default rules generally apply to the newly-developed business form called the Limited Liability Company (LLC). See, for example, U. L. L. C. A $\$ \$ 601,602,701$ (describing how LLC members have presumptive right to disassociate from LLC at any time and to demand the LLC repurchase their interest for its fair value).

${ }^{7}$ To say that firm-specific assets lose their value when withdrawn from the firm does not mean that all such assets can be locked in. Employees can leave firms relatively easily, for example, and when they do the value of their firm-specific human capital evaporates. Sometimes, however, it is possible to lock in investments, as in the case of the widget factory described in the text. Locking in such investments can protect the value of other firm-specific assets by ensuring that the firm will remain alive and healthy for some period.
} 
built, the three investors' money has now been converted into an asset that is to a large extent specific to the widget-producing enterprise. In lay terms, this means that each investor's one-third share can achieve its highest value only when combined with the other two-thirds. (A third of a customised widget factory, alone, is not worth much, perhaps no more than its value as scrap metal.)

As a result there is no easy way for any one of the three investors to withdraw his or her share without harming its value and, by extension, the collective value of the joint enterprise. Adam, Betty, and Charlie-or any successors who buy their interests-reap the highest value from their investment by keeping the widget factory together and sharing in the profits from widget production. As a result, if the business is formed as a partnership, Adam, Betty, and Charlie must now worry that at some time in the future, one of the three co-investors will want, or need, to withdraw his or her interest. Adam may stay up late nights worrying that if Betty sees a wonderful investment opportunity come along, she might want to withdraw her one-third interest from the partnership, requiring a break-up or fire sale of the factory that threatens much of the value of the other two-thirds. Betty may similarly worry that Charlie, who is a compulsive gambler, will go to Atlantic City and lose big at the craps table, and that Charlie's creditors-husky men with five o'clock shadows and New Jersey accents-may demand the value of his share, requiring the factory to either be dismantled or sold in a hasty fashion that threatens Betty's investment.

Co-investors who contribute to projects that require large amounts of firm-specific investment accordingly can find themselves at risk from each other, and from each others' creditors. ${ }^{8}$ At the extreme, one could even imagine the spectacle of Adam, Betty and Charlie each opportunistically threatening to withdraw his or her onethird interest in the widget partnership-- in effect, each threatening to take his or her third of the factory and go home-unless given $90 \%$ of the profits. ${ }^{9}$

Unless these risks can be tempered, investors like Adam, Betty and Charlie might well decide against pooling their money to build a widget factory in the first place. Similarly, other complex economic projects that require the commitment of large amounts of specific assets over long periods of time-for example, building railroads, canals, assembly lines, retail brands, communications networks, or software empires-may be discouraged if equity investors are free to unilaterally withdraw their interests. As Demsetz has put it, 'The corporation ... cannot be in continual jeopardy of losing its assets to disappointed shareholders. ${ }^{, 10}$

\footnotetext{
${ }^{8}$ Henry Hansmann and Reinier Kraakman have emphasised how specific investments can pose problems for potential creditors of a joint enterprise, making it more difficult for large-scale joint enterprises to borrow money unless they can somehow assure lenders that essential specific assets will remain within the firm. See Hansmann and Kraakman, above $\mathrm{n} 2$.

${ }^{9}$ As Larry Ribstein has pointed out, such extreme behavior might give rise claims of bad faith. See Larry E Ribstein, 'Are Partners Fiduciaries?', University of Illinois Law Review (forthcoming, 2004) (May 27 draft) 35.

${ }^{10}$ See Demsetz, above n 3, 51.
} 
This is where the creation of an incorporated legal entity comes in handy. Suppose that, instead of pooling their funds in a partnership, Adam, Betty and Charlie each contribute money to a corporation in return for a third of its stock. Now the corporation uses the funds to build the widget factory. The factory belongs to the corporate entity-not to Adam, Betty, and Charlie, who own only stock. Owning stock gives them a right to cast votes to elect the corporation's board of directors, and to participate in any dividends the board declares. It does not, however, give them the unilateral right to withdraw their interests. The factory can only be broken up, sold off, or distributed to the shareholders if this is agreeable to the party that as a matter of law controls the corporation's assets - the corporation's board of directors. The end result is that, as long as neither Adam, nor Betty, nor Charlie enjoys complete control over the board (as none of three can without owning a clear majority of shares) all have "tied their own hands" by making it harder to withdraw their investments. ${ }^{11}$ This apparently self-defeating behaviour may in fact be self-serving, if it encourages profitable joint investment in the first place.

The growing literature on capital lock-in accordingly suggests how an ability to stop investors (and their creditors) from subsequently withdrawing their interests in a joint project may be essential to many forms of economic production. This does not mean that incorporation locks in capital completely: for example, under some circumstances, shareholders owning a majority or supermajority of shares can collectively demand a corporation be liquidated, or vote out a recalcitrant board that refuses to pay them a dividend as large as they would like. Nor is incorporation the only way to lock in capital. One could imagine a web of formal agreements, contracts, and trusts by and among partners and their creditors that accomplish the same goal.

But as both Blair and Hansmann and Kraakman have explained in some detail, incorporation may often be the cleanest, cheapest, and most effective way to lock assets into a joint enterprise. ${ }^{12}$ This observation may do much to explain the growth of the corporation into the dominant form of large-scale business today. It may also be essential to understanding many aspects of corporate law and practice that are difficult to explain if we focus only on such much-cited corporate characteristics as limited liability, perpetual life, centralised management, or free transferability of interest.

To test this hypothesis, ${ }^{13}$ I consider below whether the corporate characteristic of capital lock-in can offer insight into puzzles raised by three participants in the

\footnotetext{
${ }^{11}$ See Stout, 'The Shareholder As Ulysses', above n 5. This analysis does not, of course, apply to corporations that have a single shareholder, and it applies to a lesser degree to firms with a single controlling shareholder. Such situations are relatively rare, however. Casual observation suggests that the vast majority of active, operating corporations of any significant size have multiple shareholders who have significant blocks, even though those shareholders may be relatively few in number.

${ }^{12}$ See sources in above n 2,5 .

${ }^{13}$ Because I did not select these three puzzles - the scholars who raised them were assigned to me for commentary before the conference organizer had any notion of my thesis-self-selection is not an issue in determining the results of the test. Sample size certainly may be.
} 
Symposium titled Uncorporation: A New Age, held at the University of Illinois College of Law in April 2004, where this article was originally presented. These puzzles are (1) the unique nature of corporate directors' fiduciary duties; (2) the distinction, if any, between corporations and partnerships in a world with both small close corporations and large-scale partnerships; and (3) the relative fondness state and federal lawmakers in the US seem to display for meddling with the rules that govern corporate entities.

\section{Three PuZZLES}

Let us begin with the puzzle raised by Larry Ribstein's contribution to the symposium: whether the duties that partners in a partnership owe each other can be described as fiduciary duties. ${ }^{14}$

Ribstein argues that it is a mistake to apply the concept of fiduciary duty to the relationship between partners in a partnership. He suggests such broad use glosses over an important reality: partners are burdened with duties that are quite different from the archetypal fiduciary duties corporate law imposes on corporate directors. In particular, Ribstein emphasies that corporate directors are burdened by what he calls "a duty of unselfishness" - a legal demand that in managing the firm, they consider only what is best for the firm and its shareholders, and pay no attention whatsoever to what is best for themselves. ${ }^{15}$

Two clarifications are worth making before we explore this idea further. First, Ribstein's argument compares partners' duties with those of corporate directors. ${ }^{16}$ Many corporate scholars might find this comparison jarring from the start. In many ways, partners' fiduciary duties seem to map much more closely onto the duties that corporate law imposes on controlling shareholders, than the duties corporate law imposes on directors. This observation, and a possible explanation for it, are explored in greater detail below.

Second, Ribstein's "duty of unselfishness" might be more clearly labelled, at least in the director context, as a "duty of extreme unselfishness." Most legal rules demand some degree of unselfish behaviour. The law against murder, for example, requires us to refrain from taking others' lives even when this would be personally convenient or satisfying. Yet as Ribstein observes, the degree of unselfishness required of corporate directors goes far beyond what law demands of us in most contexts. The rule of negligence, for example, demands we refrain from accidentally injuring others when the probable losses (to them) exceed the costs of taking

\footnotetext{
${ }^{14}$ See Ribstein, above $\mathrm{n} 9$.

15 Ibid 9.

${ }^{16}$ Ibid 4-5.
} 
precautions (to us). But we are free to behave selfishly by imposing "efficient" risks on others. ${ }^{17}$

In contrast, a corporate director's fiduciary duty of loyalty precludes her from considering her own interests to any extent. In making business decisions, directors are supposed to focus only on what's best for the firm and its shareholders. They are also restricted from using their positions to extract any personal pecuniary benefit beyond their agreed-upon directors' fees. If a director should find herself in a situation where she could personally profit from voting for one business strategy rather than another (as directors sometimes do, especially when they also fill executive roles), the business judgment rule no longer insulates her decision from judicial scrutiny. Instead, if a director takes a "corporate opportunity" or enters an "interested" transaction with her firm, a disgruntled shareholder can bring a claim of breach of duty of loyalty, and the burden will be on the director to demonstrate to the court that her decisions were intrinsically fair to the firm and its shareholders. ${ }^{18}$

Partnership law takes quite a different approach. Unlike corporate directors, partners are not burdened with a duty of extreme unselfishness: they are not automatically subject to legal scrutiny when they make decisions that enrich themselves. To the contrary, this is an expected benefit of being a partner. Of course, partners are subject to other duties, including the basic requirement that, when a partner causes the partnership to distribute wealth, he be prepared to share that wealth with his fellow partners. ${ }^{19}$ But no one expects partners to ignore their own interests in making business decisions.

Why does corporate law demand so much more selflessness from corporate directors than the default rules of partnership demand from partners? Ribstein argues the answer can be found in the relative vulnerability of investors in firms with centralized management. Looking at the problem through the lens of the capital lock-in literature offers deeper insight into this explanation.

In brief, the idea that corporations exist primarily to lock in capital suggests that corporate directors and partners are burdened with different legal duties because they play very different economic roles in firms. Partners are co-investors who expect to act as "residual claimants" in the partnership: that is, to share in any

\footnotetext{
${ }^{17}$ See David W Barnes and Lynn A Stout, Cases and Materials on Law and Economics (1992) (discussing rule of negligence).

${ }^{18}$ See generally Blair and Stout, 'Team Production', above n 5, 298-99 (discussing duty of loyalty). In addition to their duty of loyalty, directors in the US also owe their firms a duty of care. The duty of care demands a more limited degree of unselfishness in the sense that, like the negligence rule, it requires directors only to exercise "reasonable" (not obsessive) care. Thus after directors have met some minimum standard, they can devote the balance of their time and attention to their own projects. The degree of self-interested director behavior allowed under the duty of care is expanded still further by the business judgment rule, which insulates directors from liability for their decisions provided they do not extract any personal benefit and are duly "informed." See generally Lynn A Stout, "In Praise of Procedure: An Economic and Behavioral Defense of Van Gorkom and the Business Judgment Rule' (2002) 96 Northwestern University Law Review 765.

${ }^{19}$ See Ribstein, above n 9, 37 (discussing sharing rule in partnerships).
} 
profits the business makes after it has paid its contractual debts to its employees, creditors, and so forth. The economic role that partners play in partnerships thus is analogised best not to the role played by directors in corporations, but to the role played by shareholders. This is why the "fiduciary duty" corporate law imposes on controlling shareholders-most significantly, a duty not to use their control over the firm to cause the firm to make payments to them that the minority shareholders do not also receive- resembles the sharing duty partnership law imposes on partners. $^{20}$

Directors play a very different part in corporations, and as a consequence, are subject to very different legal constraints. Unlike shareholders, directors qua directors are neither investors nor residual claimants in the firm. ${ }^{21}$ Indeed, a director can join a board without making any investment whatsoever, and her only legal claims on the firm's assets are her right to her promised director's fee and her right to be indemnified for expenses she incurs on the corporation's behalf. Thus corporate directors, unlike shareholders or partners, have no incentive to try to withdraw essential assets from the corporation. To the contrary, if they want to keep their firms alive and healthy (and so keep their positions as directors), they want to discourage other groups, such as shareholders, from trying to withdraw too large a share of the firm's assets.

In other writings, Margaret Blair and I have explored this peculiarity of director's incentives in some detail. We propose that it explains why shareholders in public corporations take the otherwise-puzzling step of ceding control over firms to boards in the first place. ${ }^{22}$ Applying team production analysis, we argue that co-investors in projects that need large commitments of specific capital often understand intuitively that, in order to protect the value of the joint project, they need to place control over it into the hands of someone who has neither motive nor easy opportunity to profit from withdrawing assets from the firm. ${ }^{23}$ In a corporation, this

\footnotetext{
${ }^{20}$ Ibid 17 (discussing sharing rule applied to controlling shareholders); see also James D Cox and Thomas Lee Hazen, Corporations (2003) 258 (noting that especially in close corporations, 'the controlling shareholder's fiduciary obligation is increasingly being viewed as akin to the obligation that partners owe to one another').

${ }^{21}$ Individuals who serve as directors of the firm may be able to extract assets from the firm if they also play roles as shareholders or officers. When they do, however, their decisions are no longer privileged under the business judgment rule, but are instead subject to additional legal duties and judicial oversight. See text in above n 15-18 (discussing directors' interested transactions and controlling shareholders' duties).

${ }^{22}$ See generally Blair and Stout, 'Team Production', above n 5, 315-19 (discussing directors' role); Stout, 'Shareholder as Ulysses', above n 5, 685-88 (discussing directors' incentives).

${ }^{23}$ This solution to the problem of encouraging specific joint investment has a catch, of course. Because directors are not residual claimants, they do not have an incentive to withdraw resources from the firm, but they also do not have an incentive to run the firm with maximum efficiency. Instead, as we actually observe, directors manage firms in a satisficing, but suboptimal, fashion. This "second best" solution may nevertheless be the most attractive of the available alternatives in a world where economic production can require massive amounts of firm-specific investment that cannot be adequately protected by formal contract. See generally Blair and Stout, 'Team Production', above n 5, 319 (discussing second best nature of board governance); Stout, 'Shareholder as Ulysses', above n 5, 685-88 (same).
} 
"someone" is a board of directors subject to the severe constraints on self-interest imposed by the rules of fiduciary duty.

Understanding the unusual role directors play in corporations consequently sheds light on the sui generis nature of directors' fiduciary duties. It also supports Ribstein's argument that we may lose important information when we apply the same label to directors' duties that we apply to the duties partners and shareholders owe each other. And it is certainly a mistake to apply the word "fiduciary" to still-moredistant relationships, such as relationships among family members. Thus Ribstein rightly criticises the Second Circuit's opinion in Chestman v United States, which suggested that confidential relationships among various members of the Waldbaum family might give rise to "the functional equivalent of a fiduciary relationship" for purposes of creating insider trading liability. ${ }^{24}$

A focus on the capital lock-in function of incorporation, and on the unique governance role boards of directors play in upholding that function, accordingly helps explain both the peculiar nature of director's fiduciary duties as "mediating hierarchs" in a public corporation, and the ways these duties differ from partners' and shareholders' duties to each other as co-investors. ${ }^{25}$ Similarly, it may offer insight into a second problem explored in the symposium, in Robert Hillman's paper on the distinctions between partnerships and corporations in terms of bargaining and management structure. ${ }^{26}$

Hillman's paper starts with a conundrum. He notes that one of the standard distinctions thought to exist between partnership law and corporate law is that partnerships are believed to be more flexible, and to permit a much greater degree of bargaining over firm structure than normally is practicable in a corporation. He also notes that egalitarian management and shared power are thought to be hallmarks of a partnership. In contrast, highly centralised and hierarchical management styles are thought to be the norm in corporations.

Hillman then points out a pair of interesting and telling anomalies. These are small, closely-held corporations, and large modern partnerships such as law firms or accounting firms. Hillman argues that these common business forms pose a chal-

\footnotetext{
${ }^{24}$ United States $v$ Chestman, 947 F.2d 551, 571 (2d Cir. 1991), cert den., 503 U.S. 1004 (1992). See Ribstein, above n 9, 21-22 (discussing the Chestman decision). As Ribstein describes in some detail, such loose use of legal language can be costly, increasing the cost of negotiating transactions, increasing the risk of opportunistic litigation, and raising the possibility that overuse will 'squander the moral authority' of courts who employ the word 'fiduciary.' Ibid 29. Although at the end of the day one might conclude that there is little harm done by applying the word 'fiduciary' broadly so long as courts and business people understand the distinction between the relationships and duties that business participants owe each other in particular circumstances, I believe Ribstein has succeeded in placing the burden of persuasion on those who would advance this argument.

${ }^{25}$ See generally Blair and Stout, 'Team Production', above n 5, 276-87 (discussing directors' roles as mediating hierarchs).

${ }^{26}$ See Robert W Hillman, 'The Bargain in the Firm: Partnership Law, Corporate Law, and Private Ordering With Closely-Held Business Associations', University of Illinois Law Review (forthcoming 2004)(April 9 draft).
} 
lenge to any claim that partnerships are characterised by flexibility and more egalitarian management than corporations. After all, in the typical close corporation there may a great deal of effort devoted to negotiating customised charter terms and bylaws (or what's referred to in Australia as the 'corporate constitution'), and shareholder agreements, and this flexibility is supported by the basic rules of corporation law. Close corporation shareholders also usually are active participants in the firm's day-to-day management. Conversely, in a large service partnership (think of the law firm or accounting firm with offices in ten different cities), it is unrealistic to believe that any real bargaining occurs when a new partner is welcomed into a thousand-member firm. Moreover, and in contrast to the egalitarian management observed in many close corporations, these large partnerships are usually characterised by the same sorts of hierarchical management structures we see in the Fortune 500 .

In other words, Hillman observes, neither the presence nor the absence of bargaining, nor the choice of centralised or decentralised management, seem to be immutable characteristics of either partnerships or incorporated business forms. What then distinguishes the two ? $^{27}$

Incorporation's capacity to lock in investor capital may provide the answer. In particular, a focus on capital lock-in suggests that incorporation may often be attractive not because it makes centralised management easier or when flexibility is unnecessary, but because a particular form of economic production demands a high degree of firm-specific investment, making an ability to keep those investments in the firm essential to the firm's health.

This approach offers a useful and testable prediction: we should expect to see systematic differences between the types of businesses that are incorporated as large corporations, and the types that are run as large partnerships. Most obviously, we should expect large firms to be organised as partnerships only for economic projects where firm-specific investment either is relatively unimportant, or locking in that investment is for some reason impracticable.

This approach may explain why large partnerships have evolved primarily in clientcentered service industries like accounting and law. In these industries, human capital investments often are the primary source of firm value. To a very large extent, those human capital investments are not firm-specific but instead take form of general human capital (eg, active membership in a particular legal association or expertise in a type of accounting) that a partner can easily take from one firm to another. Much of the balance may be "client-specific" human capital-knowledge of and contacts with a particular client - which again can often be moved relatively easily, with little loss in value. Thus, because firm-specific investment is of relatively little importance to the typical law or accounting firm (and, given the mobil-

\footnotetext{
${ }^{27}$ At one time it might be argued that professional rules precluded law firms from incorporating. Now, however, most states permit law firms to incorporate or to use "professional corporation" business forms. A high percentage of large law firms nevertheless retain a partnership structure.
} 
ity of labour, very difficult to lock in anyway), the capital lock-in advantages of incorporation have little appeal. ${ }^{28}$

A focus on capital lock-in consequently may promote a better understanding of the fundamental economic differences between partnerships and corporations just as it promotes a better understanding of the unique nature of director's fiduciary duties. Can it also tell us something about the third puzzle posed by Saul Levmore in his remarks at the symposium conference at the University of Illinois College of Law: the puzzle of why both state and federal lawmakers in the US seem so much more willing to meddle in (and so much more interested in meddling with) the governance rules that apply to corporations, than the rules that apply to unincorporated business forms? ${ }^{29}$

Once again, capital lock-in provides at least some of the answer. This is not to suggest capital lock-in explains all the enthusiasm lawmakers show for regulating corporations, or that other explanations may not exist as well. Yet corporations' unique ability to attract and lock in large amounts of firm-specific investment - an ability derived in large part from the possibility of lock-in-may go far towards explaining why zealous regulators seem far more interested in intervening in the "internal affairs" of corporations, than they do in intervening in the internal governance structures of other sorts of business organisations.

In brief, by acting as sinks for large amounts of firm specific investment, corporations make themselves especially tempting targets for "rent-seeking" legislation. This argument relies on the so-called economic theory of legislation, which posits that interest groups often seek to "bribe" lawmakers with campaign contributions and lobbyist attention, in hope of getting them to pass legal rules that favour the interest group (often at some other group's expense). ${ }^{30}$ Savvy regulators may also seek to extract "blackmail" payments from interest groups by entertaining proposed changes in law or regulation that threaten those groups' welfare. ${ }^{31}$ Because of capital lock-in, corporations should attract this type of lawmaking, and this type of lawmaker, the way a large carcass attracts flies.

To understand why, it is important to understand that board governance does more than encourage equity investors to make investments in corporations. By locking in capital, board governance also attracts firm-specific investments and commitments

\footnotetext{
${ }^{28}$ Anecdotal evidence of the relative unimportance of firm-specific investment to lawyers and accountants may be found by observing what happens to lawyers and accountants whose firms collapse (e.g., the accountants at Arthur Anderson). My sense is that most of these individuals quickly find similar positions at other firms.

${ }^{29}$ See comments of Saul Levmore, University of Illinois College of Law Conference on Uncorporation: A New Age, held April 23, 2004, Chicago, Illinois.

${ }^{30}$ See generally Barnes and Stout, above n 17, 476-91 (surveying theory of interest group rent-seeking).

${ }^{31}$ See Fred S McChesney, 'Rent Extraction and Interest-Group Organization in a Coasean Model of Regulation' (1991) 20 Journal of Legal Studies 73 (arguing that lawmakers sometimes blackmail interest groups).
} 
from a variety of other groups as well. ${ }^{32}$ Unsecured creditors, for example, may be more willing to lend to the firm. Employees from the shop floor to the corner office may be more willing to acquire firm-specific skills and to contribute extra hours and extra effort. Even customers and the local community may make specific investments and contributions, on the assumption the firm will stick around for some period of time - consider the case of the consumer who masters a particular software program, or the town that builds roads, schools, and other specialised infrastructure to support a factory.

By attracting large amounts of specific investment from so many different constituencies, corporations turn these constituencies into potential adversaries who may benefit or suffer from changes in the firm's structure that reallocate shares of the corporate pie. Shareholders seeking better profits, for example, may lobby to shut down expensive US-based production and move manufacturing abroad, while local employees and communities lobby to keep factories at home. Normally such competing constituencies focus their attentions on the company's board of directors, trying to convince the board to adopt whichever business strategy favours their interests. Shareholders ask for larger dividends, executives seek bigger bonuses, and rank-and-file employees lobby for pensions or a better health plan.

As an alternative, however, competing corporate constituencies can sometimes try to do an end run around board governance by turning to lawmakers as vehicles for rent seeking from other participants in the firm-other participants who can't protect their firm-specific interests simply by withdrawing them. Lawmakers accordingly can attract a great deal of attention (and campaign contributions) by responding to appeals from various corporate participants to change the rules in the middle of the corporate game. Consider, for example, how a state legislator considering a "constituency statute" might suddenly become popular with unions, institutional investors, and the Business Roundtable. Similarly, the Securities Exchange Commission in recent months has enjoyed the frenzied attention of the business world by playing with the notion of "reforming" the shareholder proxy process to give shareholders greater power. ${ }^{33}$

These sorts of regulatory initiatives tend to provoke strong reactions from various corporate constituencies, because those constituencies have large amounts of firmspecific investment at risk. In contrast, legislators have far less power to threaten the interests of investors in enterprises who can easily withdraw their investments. Any legislative attempt to intervene in the "internal affairs" of large law partnerships, for example, is unlikely to provoke much in the way of lobbying efforts or campaign contributions. The reason is simple-unlike shareholders whose interests are diluted by executive stock options or communities whose economies rely on a

\footnotetext{
${ }^{32}$ See generally Blair and Stout, 'Team Production', above n 5, 302-09; Stout, 'Bad and Not-So-Bad Arguments', above n 5, 1195-98.

${ }^{33}$ See, for example, Louis Lavelle, Governance: Backlash in the Executive Suite, Business Weekly, June 14, 2004, 37 (describing how the US Securities Exchange Commission's proposal to change proxy rules has triggered lobbying by a variety of institutional investors, union organisations, and corporate managers, as well as the Business Roundtable in the US).
} 
factory, a disgruntled law partner can simply leave one law firm to join or start another, taking his general human capital and client-specific human capital with him. Thus regulators and politicians like to tinker with corporate governance rules more than they like to tinker with partnership governance rules for the same reason Willy Sutton liked to rob banks: because that's where the money is.

\section{CONCLUSION}

This article has explored the value of the concept of capital lock-in as a fundamental characteristic of corporations by suggesting how it may shed light on three different corporate mysteries: the unique nature of directors' fiduciary duties; the evolution of the large modern service partnership; and the peculiar fascination lawmakers seem to have for tinkering with the rules that govern corporations' internal affairs. In each case, inspecting the problem through the lens of the emerging scholarship on capital lock-in goes a long way towards developing our understanding. These three examples accordingly support the view that capital lock-in is an essential, if previously overlooked, characteristic of the corporate form that does much of the work that needs to be done to distinguish corporations from unincorporated business forms.

This observation is subject to two important caveats. First, I do not intend to suggest that capital lock-in is somehow unique to corporations. How easily equity investors can withdraw their investments is a variable that exists along a continuum of business forms. At one extreme of the continuum, the owner of a sole proprietorship can withdraw resources almost without restriction. At the other extreme, in large public corporations, shareholders' returns depend almost entirely on the decisions of a board largely insulated from their command and control. Partnerships, limited partnerships, close corporations, and the US business form known as the LLC lie somewhere in between, depending on their structure and governance provisions. And just as we have seen a trend toward allowing other business forms to adopt such typically corporate characteristics as limited liability or centralised management, we can expect to see business law move (perhaps more slowly) toward allowing other forms to adopt greater capital lock-in. ${ }^{34}$

The second caveat is that, in exploring the role of capital lock-in, I do not intend to suggest that other variables that corporate scholars traditionally have emphasised are somehow unimportant or irrelevant. To the contrary, there are a variety of significant issues in business law and practice that are best understood by focusing on such traditionally-emphasised corporate characteristics as limited liability or free

\footnotetext{
${ }^{34}$ An example may be found in the default rules for limited liability partnerships in the US, which do not permit limited partners to unilaterally dissociate from the firm and demand its winding up, but give unilateral withdrawal rights only to general partners. See U. L. P. A $\$ \$ 601-604,801-803$ (describing rules for limited partner disassociation and for dissolving and winding up limited partnerships after disassociation of general partner).
} 
transferability of shares (although in some cases, these characteristics may themselves be better understood by taking account of lock-in). ${ }^{35}$ To return to the parable, just as each of the blind men was correct to say that the elephant was like a snake, a rope, and a tree, corporate scholars and practitioners are correct to observe that public corporations tend to have limited liability, perpetual life, centralised management, and freely transferable shares, and that each of these can explain many aspects of business law and practice.

Nevertheless, there is reason to suspect that for now and for many years to come, the scholarly returns from analysing corporations through the lens of the emerging literature on capital lock-in may often exceed the scholarly returns from following more customary approaches. In part this is because the idea of capital lock-in is relatively novel, and its scholarly terrain has only begun to be explored. As a result the new school holds great promise for explaining a wide variety of issues that have long troubled corporate scholars and practitioners. Yet innovation alone may not explain all the power of this emerging concept. Board governance and capital lockin, while not the only characteristics to separate corporations from other business forms, may well prove in many cases to be the most vital and unique characteristics. Put differently, if I were forced to choose, I would adopt the perspective of the blind man who thought the elephant resembled a wall. Like the scholar or practitioner who thinks the corporation resembles a partition, he may have come closest to the heart of the beast.

\footnotetext{
${ }^{35}$ For example, corporations may have evolved freely transferable shares as a means of compensating for the illiquidity equity investors would otherwise suffer as a result of lock-in.
} 